\title{
PENGETAHUAN SISWA TENTANG SEKS PRANIKAH DI SMA NEGERI 1 BERASTAGI TAHUN 2017
}

\author{
Susanti br Perangin-Angin* \\ Dosen Poltekkes Kemenkes Medan
}

\begin{abstract}
Sexuality issues until recently an interesting topic that is always discussed. One of the sexual problems that are often discussed premarital sex. Negative impact of premarital sex is very disturbing society. Dai recent survey in 33 provinces in 2008 by the National Family Planning Coordinating Board (BKKBN) reported 63\% of adolescents in Indonesia between the ages of SMP and high school already having sexual relations outside marriage. The percentage of teens who had sexual intercourse before marriage has increased compared to previous years. This study aims to determine the level of knowledge of students of SMA Negeri 1 Berastagi Karo District Berastagi about premarital sex. Research is descriptive research, sample number as many as 50 people. Sampling technique using total sampling technique that is all the population sampled data was collected using questionnaires and interviews. Data analysis using desscriptive statistics. Test results of students' level of knowledge of SMA Negeri 1 Berastagi Karo District Berastagi regarding premarital sex by $58 \%$ were categorized with poor knowledge. From the results of these studies are expected to the school and parents can play an active role in providing information on reproductive health and sex education to the students.
\end{abstract}

Keywords : free sex, teen, level of knowledge

\section{PENDAHULUAN}

\section{Latar Belakang}

Kesehatan merupakan hak asasi manusia dan salah satu unsur kesejahteraan yang harus diwujudkan sesuaiyang dengan cita - cita bangsa Indonesia, sebagaimana dimaksud dalam Pancasila dan UndangUndang Negara Republik Indonesia tahun 1945. Berkaitan dengan hal itu, undang-Undang Republik Indonesia Nomor 36 Tahun 2009 tentang program Kesehatan menyatakan bahwa derajat kesehatan masyarakat yang setinggi-tingginya dicapai melalui penyelenggaraan pembangunan kesehatan (Kementerian Kesehatan Republik Indonesia,2011).

Remaja dalam memasuki masa peralihan tanpa pengetahuan yang memadai tentang seksual pranikah. Hal ini disebabkan orang tua merasa tabu membicarakan masalah seksual dengan anaknya dan hubungan orang tua anak menjadi jauh sehingga anak berpaling ke sumbersumber lain yang tidak akurat khususnya teman (Sarwono, 2006).

Remaja banyak yang tidak sadar dari pengalaman yang tampaknya menyenangkan justru dapat menjerumuskan, salah satu problema dari kaum remaja apabila kurangnya pengetahuan seksual pranikah adalah kehamilan yang tidak diinginkan, aborsi tidak aman dan juga penyakit kelamin (Chyntia,2003). Pengetahuan tentang seksual pranikah dapat mempengaruhi sikap individu tersebut terhadap seksual pranikah. (Adikusuma,2005).

Sikap seksual pranikah remaja banyak dipengaruhi oleh banyak hal, selain dari faktor pengetahuan juga dipengaruhi oleh faktor kebudayaan, orang lain yang dianggap penting, media massa, pengalaman pribadi, lembaga pendidikan, lembaga agama dan emosi dari dalam individu. Sikap seksual pranikah remaja bias berwujud negatif atau positif, sikap positif kecenderungan tindakan adalah mendukung seksual pranikah sedangkan sikap negative kecenderungan tindakan adalah menghindari seksual pranikah remaja (Azwar,2009)

Remaja mulai mempersiapkan diri menuju kehidupan dewasa, termasuk dalam aspek seksualnya. Dengan demikian dibutuhkan sikap yang bijaksanadari para orang tua, pendidik dan masyarakat pada umumnya serta tentunya dari remaja itu sendiri, agar mereka dapat melewati masa transisi itu dengan selamat (Sarwono, 2006).

Menurut Sarwono (2006), ada beberapa factor yang dianggap berperan dalam munculnya permasalahan seksual pada remaja, diantaranya perubahan-perubahan hormonal yang dapat meningkatkan hasrat seksual remaja, penyebaran informasi yang salah misalnya dari buku-buku dan VCD porno, rasa ingin tahu yang sangat besar, serta kurangnya pengetahuan yang didapat dari orang tua dikarenakan orang tua mengganggap hal tersebut tabu untuk dibicarakan. 
Terdapat beberapa alasan lain yang menyebabkan remaja pada akhirnya melakukan seks pranikah. Diantaranya sebagai bukti cinta dan sangat mencintai pacar, dijanjikan akan menikah, rasa ingin tahu yang sangat tinggi tentang seksualitas, ingin mencoba, takut mengecewakan pacar, takut diputus pacar serta kurangnya pengetahuan tentang seksualitas yang didapat dari keluarga dan sekolah. Umumnya remaja kurang menyadari akibat-akibat buruk yang dapat ditimbulkan dari perilaku seks bebas tersebut, seperti kehamilah, putus sekolah, tertular penyakit kelamin dan HIV/AIDS. Kurangnya pengetahuan yang didapat dari orang tua dan sekolah mengenai seksualitas membuat para remaja mencari tahu sendiri dari teman atau lingkungan bermainnya yang bias saja pengetahuan tersebut salah.

Berdasarkan hal tersebut diatas maka sangat diperlukan adanya pengetahuan seks yang benar bagi remaja. Pengetahuan seks yang tentu saja bertujuan untuk membimbing dan menjelaskan tentang perubahan fungsi organ seksual sebagai tahapan yang harus dilalui dalam kehidupan manusia serta dengan penanaman nilai-nilai seksualitas itu sendiri.

Selama ini pendidikan seks telah dilakukan dibeberapa sekolah, namun jarang sekali memasukkan unsur nilai-nilai seksualitas didalamnya. Untuk itu penelitian ini dilakukan guna mengetahui sejauhmana tingkat pengetahuan siswa terhadap Seks Pranikah di Sekolah Menengah Atas (SMA) Negeri 1 Berastagi Tahun 2017.

\section{B. Perumusan Masalah}

Berdasarkan uraian diatas, maka penulis merumuskan permasalahan sebagai berikut : "Bagaimana tingkat pengetahuan siswa terhadap Seks Pranikah di Sekolah Menengah Atas (SMA) Negeri 1 Berastagi Kabupaten Karo Tahun 2017 ?

\section{METODE PENELITIAN}

\section{a. Jenis Penelitian}

Penelitian ini merupakan penelitian yang bersifat deskriptif untuk menggambarkan tingkat pengetahuan dan sikap tentang seks pranikah pada anak SMA Negeri 1 Berastagi Kabupaten Karo.

\section{b. Waktu dan Tempat penelitian}

Penelitian ini dilakukan pada bulan Maret April 2017 di SMA Negeri 1 Berastagi Kabupaten Karo.

\section{c. Populasi dan sampel}

Populasi penelitian ini adalah Siswa Kelas 10 SMA Negeri 1 Berastagi Kecamatan Berastagi Kabupaten Karo Semester Genap Tahun 2017 yang berjumlah 421 siswa dimana kelas 10 terdiri dari lakilaki berjumlah 190 orang dan perempuan berjumlah 231 orang.

1. Kriteria Inklusi

Sampel merupakan siswa terpilih yang hadir pada saat pengambilan sampel.

2. Kriteria Eksklusi a. Sampel yang tidak bersedia diwawancarai

Metode sampling yang digunakan dalam penelitian ini adalah non probability sampling yaitu quota sampling. Untuk penetapan keterwakilan sampel terhadap populasi ditentukan sampel sebesar 50 siswa kelas 10 SMA Negeri 1 Berastagi.

\section{Pengumpulan Data}

Data yang digunakan dalam penelitian ini adalah data primer yang diperoleh melalui pembagian kuesioner dan diikuti dengan wawancara langsung dengan anak Sekolah menengah atas (SMA) Negeri 1 Berastagi Kabupaten Karo

\section{Aspek Pengukuran}

Dalam aspek pengukuran ini dilakukan untuk mengetahui gambaran tingkat pengetahuan dan sikap tentang Seks Pranikah adalah sebagai berikut :

\section{Pengetahuan}

Adapun kriteria pertanyaan tingkat pengetahuan mempunyai enam pilihan dengan pemberian skor sebagai berikut :

A. Skor jawaban pertanyaan nomor $1 \mathrm{~s} / \mathrm{d} 15$ yaitu

1. 1 item jawaban benar maka skor dikali 1

2. 2 item jawaban benar maka skor dikali 1

3. 3 item jawaban benar maka skor dikali 1

4. 4 item jawaban benar maka skor dikali 2

5. 5 item jawaban benar maka skor dikali 2

6. tidak tahu maka skor dikali 1

Berdasarkan kriteria pemberian skor, pengetahuan anak sekolah dikategorikan dengan skala pengukuran sebagai berikut :

Jadi Pengetahuan dikategorikan baik jika skor 76\%-100\% dan kurang baik jika skor $<76 \%$.

\section{Analisa Data}

Analisa data dilakukan analisa untuk menggambarkan (mendeskripsikan) masing-masing variabel yang selanjutnya disajikan menggunakan tabel distribusi frekuensi.

\section{Hasil Penelitian}

\subsection{Karakteristik Responden}

Untuk mengetahui karakteristik responden di SMA Negeri 1 Berastagi Kabupaten Karo maka dilakukan pengumpulan data melalui kuesioner yang diikuti dengan wawancara pada siswa tersebut. Berikut hasil pengumpulan data mengenai karakteristik responden yang terdiri dari umur responden dan sumber informasi tentang kesehatan dari responden. 


\subsubsection{Umur Responden}

Tabel 1. Distribusi responden berdasarkan umur responden di SMA Negeri 1 Berastagi Kabupaten Karo Tahun 2017

\begin{tabular}{llll}
\hline No. & $\begin{array}{l}\text { Umur } \\
\text { Responden } \\
\text { (tahun })\end{array}$ & $\begin{array}{l}\text { Jumlah } \\
\text { (n) }\end{array}$ & $\begin{array}{l}\text { Persentase } \\
(\%)\end{array}$ \\
\hline 1 & 14 & 1 & 2 \\
\hline 2 & 15 & 16 & 32 \\
\hline 3 & 16 & 31 & 62 \\
\hline 4 & 17 & 2 & 4 \\
\hline & & 50 & 100 \\
\hline
\end{tabular}

Tabel 1 diatas menyimpulkan bahwa umur responden yang terbanyak adalah umur 16 tahun yaitu sebanyak 31 orang ( $62 \%$ ) dan yang paling sedikit berumur 14 sebanyak 1orang (2\%).

\subsubsection{Sumber Informasi Tentang Kesehatan}

Tabel 2. Distribusi responden berdasarkan sumber informasi tentang kesehatan responden di SMA Negeri 1 Berastagi Kabupaten Karo Tahun 2017

\begin{tabular}{cccc}
\hline No. & Sumber & Jumlah & Persentase \\
& Informasi & $($ n) & $(\%)$
\end{tabular}

\begin{tabular}{cccc}
\hline 1 & Media cetak & 6 & 12 \\
\hline 2 & Media elektronik & 11 & 22 \\
\hline 3 & Internet & 42 & 84 \\
\hline 4 & $\begin{array}{c}\text { Telepon } \\
\text { genggam }\end{array}$ & 12 & 24 \\
& $\begin{array}{c}\text { Petugas } \\
\text { kesehatan }\end{array}$ & 23 & 46 \\
\hline 5 & Guru & 25 & 50 \\
\hline 6 & Keluarga & 35 & 70 \\
\hline 7 & Teman-teman & 5 & 10 \\
\hline 8 & Tidak ada & 1 & 2 \\
\hline 9 & Tabel 2 diatas menyimpulkan bahwa & sumber
\end{tabular}
informasi tentang kesehatan responden di SMA Negeri 1 Berastagi Kabupaten Karo tahun 2017 paling banyak adalah dari adalah internet yaitu masing-masing 42 orang (84\%) dan paling sedikit dari $\mathrm{n}$ tidak ada dapat informasi dari manapun adalah sebanyak 1 orang $(2 \%)$.

\subsection{Tingkat Pengetahuan Responden}

Untuk mengetahui tingkat pengetahuan responden di SMA Negeri 1 Simpang Empat tentang Seks Pranikah dikumpulkan maka data melalui kusioner yang diikuti dengan wawancara. Berikut ini adalah hasil pengumpulan data terhadap responden di SMA Negeri Berastagi Kabupaten Karo tahun 2017 tentang pengetahuan Seks Pranikah dalam tabel distribusi dibawah ini :
Tabel 3. Pengetahuan responden tentang penyebab remaja melakukan seks pranikah di SMA Negeri 1 Berastagi Kabupaten Karo Tahun 2017

\begin{tabular}{|c|c|c|c|}
\hline No. & Pilihan & Jawaban & Jumlah \\
\hline 1 & $\begin{array}{ll}\text { Dorongan } & \text { seks } \\
\text { yang kuat } & \\
\end{array}$ & Tidak tahu & - \\
\hline 2 & Pergaualan bebas & $\begin{array}{lr}1 & \text { item } \\
\text { jawaban benar }\end{array}$ & $13 \times 1=13$ \\
\hline 3 & $\begin{array}{l}\text { Minimnya } \\
\text { pengetahuan } \\
\text { kesehatan } \\
\text { reproduksi }\end{array}$ & $\begin{array}{lr}2 & \text { item } \\
\text { jawaban benar }\end{array}$ & $20 \times 1=20$ \\
\hline 4 & $\begin{array}{l}\text { Maraknya } \\
\text { peredaran } \\
\text { porno }\end{array}$ & $\begin{array}{lr}3 & \text { item } \\
\text { jawaban } & \text { benar }\end{array}$ & $7 \times 1=7$ \\
\hline 5 & $\begin{array}{l}\text { Pengaruh } \\
\text { berbagai } \\
\text { elektronik }\end{array}$ & $\begin{array}{lr}4 & \text { item } \\
\text { jawaban } & \text { benar }\end{array}$ & $3 \times 2=6$ \\
\hline 6 & Tidak tahu & $\begin{array}{lr}5 & \text { item } \\
\text { jawaban benar }\end{array}$ & $7 \times 2=14$ \\
\hline & & Jumlah & 60 \\
\hline
\end{tabular}

Tabel 3 diatas menyimpulkan bahwa penyebab remaja melakukan seks pranikah SMA Negeri 1 Berastagi Kabupaten Karo tahun 2017 paling banyak adalah memilih 2 item jawaban yang benar diantara 6 buah pilihan jawaban yaitu sebanyak 20 .

Tabel 4. Pengetahuan responden tentang faktor penyebab remaja jatuh kedalam berbagai persoalan seks di SMA Negeri 1 Berastagi Kabupaten Karo Tahun 2017

\begin{tabular}{|c|c|c|c|}
\hline No. & Pilihan & Jawaban & Jumlah \\
\hline 1 & $\begin{array}{l}\text { Pengaruh } \\
\text { lingkungan } \\
\text { pergaulan }\end{array}$ & Tidak tahu & - \\
\hline 2 & $\begin{array}{l}\text { Akibat perubahan } \\
\text { hormonal }\end{array}$ & $\begin{array}{l}1 \text { item } \\
\text { jawaban benar }\end{array}$ & $18 \times 1=18$ \\
\hline 3 & $\begin{array}{l}\text { Kurang informasi } \\
\text { tentang seks }\end{array}$ & $\begin{array}{l}2 \text { item } \\
\text { jawaban benar }\end{array}$ & $23 \times 1=23$ \\
\hline 4 & $\begin{array}{l}\text { Orang tua yang } \\
\text { tertutup }\end{array}$ & $\begin{array}{l}3 \text { item } \\
\text { jawaban benar }\end{array}$ & $6 \times 1=6$ \\
\hline 5 & $\begin{array}{ll}\begin{array}{l}\text { Situasi } \\
\text { mendukung }\end{array} & \text { yang } \\
\end{array}$ & $\begin{array}{l}4 \text { item } \\
\text { jawaban benar }\end{array}$ & $1 \times 2=2$ \\
\hline \multirow[t]{2}{*}{6} & Tidak tahu & $\begin{array}{l}5 \text { item } \\
\text { jawaban benar }\end{array}$ & $2 \times 2=4$ \\
\hline & & Jumlah & 53 \\
\hline
\end{tabular}

Tabel 4 diatas menyimpulkan bahwa pengetahuan responden tentang faktor penyebab remaja jatuh kedalam berbagai persoalan seks di SMA Negeri 1 Berastagi Kabupaten Karo tahun 2017 yang paling banyak dipilih adalah memilih 2 item jawaban yang benar diantara 6 buah pilihan jawaban yaitu sebanyak 23 orang. 
Tabel 5. Pengetahuan responden tentang permasalahan yang dihadapi remaja dari segi perilaku seksualnya sebagian besar diakibatkan di SMA Negeri 1 Berastagi Kabupaten Karo Tahun 2017

\begin{tabular}{llll}
\hline No. & Pilihan & Jawaban & Jumlah \\
\hline 1 & Perubahan fisik & Tidak tahu & $2 \times 1=2$ \\
\hline 2 & Perubahan mental & $\begin{array}{l}1 \text { item jawaban } \\
\text { benar }\end{array}$ & $12 \times 1=12$ \\
\hline 3 & $\begin{array}{l}\text { Pengaruh } \\
\text { lingkungan }\end{array}$ & $\begin{array}{l}2 \text { item jawaban } \\
\text { benar }\end{array}$ & $18 \times 1=18$ \\
\hline 4 & Pergaulan & $\begin{array}{l}3 \text { item jawaban } \\
\text { benar }\end{array}$ & $15 \times 1=15$ \\
\hline 5 & Pengetahuan kurang & $\begin{array}{l}4 \text { item jawaban } \\
\text { benar }\end{array}$ & $3 \times 2=6$ \\
\hline 6 & Tidak tahu & $\begin{array}{l}5 \text { item jawaban } \\
\text { benar }\end{array}$ & - \\
\hline & & Jumlah & 53 \\
\hline
\end{tabular}

Dari tabel 5 diatas dapat diketahui bahwa pengetahuan responden tentang permasalahan yang dihadapi remaja dari segi perilaku seksualnya sebagian besar diakibatkan di SMA Negeri 1 Berastagi Kabupaten Karo tahun 2017 yang paling banyak dipilih yaitu memilih 2 item jawaban yang benar diantara 6 buah pilihan jawaban yaitu sebanyak 18 orang.

Tabel 6. Pengetahuan responden tentang pertanyaan apa yang pernah tentang kesehatan reproduksi di SMA Negeri 1 Berastagi Kabupaten Karo Tahun 2017

\begin{tabular}{llrll}
\hline No. & Pilihan & Jawaban & Jumlah \\
\hline 1 & $\begin{array}{l}\text { Umur } \\
\text { perkawinan }\end{array}$ & ideal & Tidak pernah & 10x1=10 \\
\hline 2 & $\begin{array}{l}\text { HIV/AIDS dan } \\
\text { penyakit kelamin } \\
\text { lainnya }\end{array}$ & $\begin{array}{l}1 \text { item jawaban } \\
\text { benar }\end{array}$ & 26x1=26 \\
\hline 3 & Aborsi & $\begin{array}{l}\text { 2 item jawaban } \\
\text { benar }\end{array}$ & $8 \times 1=8$ \\
\hline 4 & Menstruasi & $\begin{array}{l}3 \text { item jawaban } \\
\text { benar }\end{array}$ & $2 \times 1=2$ \\
\hline 5 & $\begin{array}{l}\text { Perubahan- } \\
\text { perubahan yang } \\
\text { terjai masa remaja } \\
\text { kehamilan }\end{array}$ & $\begin{array}{l}4 \text { item jawaban } \\
\text { benar }\end{array}$ & $3 \times 2=6$ \\
\hline 6 & Tidak pernah & $\begin{array}{l}5 \text { item jawaban } \\
\text { benar }\end{array}$ & $1 \times 2=2$ \\
\hline & & Jumlah & 52 \\
\hline
\end{tabular}

Dari tabel 6 diatas dapat diketahui bahwa pengetahuan responden tentang pertanyaan apa yang pernah tentang kesehatan reproduksi di SMA Negeri 1 yang paling banyak dipilih yaitu memilih 1 item jawaban yang benar diantara 6 buah pilihan jawaban yaitu sebanyak 26 orang.
Tabel 7. Pengetahuan responden tentang faktor yang memengaruhi perilaku seksual remaja di SMA Negeri 1 Berastagi Kabupaten Karo Tahun 2017

\begin{tabular}{llll}
\hline No. & Pilihan & Jawaban & Jumlah \\
\hline 1 & Pengalaman seksual & Tidak tahu & - \\
\hline 2 & Faktor keperibadian & $\begin{array}{l}1 \text { item } \\
\text { jawaban benar }\end{array}$ & $5 \times 1=5$ \\
\hline 3 & $\begin{array}{l}\text { Pemahaman dan } \\
\text { penilaian nilai-nilai } \\
\text { agama }\end{array}$ & $\begin{array}{l}\text { 2 item } \\
\text { jawaban benar }\end{array}$ & $16 \times 1=16$ \\
\hline 4 & $\begin{array}{l}\text { Berfungsinya } \\
\text { keluarga dalam } \\
\text { menjalankan fungsi } \\
\text { control }\end{array}$ & $\begin{array}{l}\text { 3 item } \\
\text { jawaban benar }\end{array}$ & 10x1=10 \\
\hline 5 & $\begin{array}{l}\text { Pengetahuan } \\
\text { tentang kesehatan } \\
\text { reproduksi }\end{array}$ & $\begin{array}{l}\text { 4 item } \\
\text { jawaban benar }\end{array}$ & $7 \times 1=7$ \\
\hline 6 & Tidak tahu & $\begin{array}{l}5 \text { item } \\
\text { jawaban benar }\end{array}$ & $12 \times 2=24$ \\
\hline & & Jumlah & 62 \\
\hline
\end{tabular}

Dari tabel 7 dapat diketahui bahwa pengetahuan responden tentang faktor yang memengaruhi perilaku seksual remaja di SMA Negeri 1 Berastagi Kabupaten Karo tahun 2017 yang banyak dipilih adalah memilih 2 item jawaban yang benar diantara 6 buah pilihan jawaban yaitu sebanyak 16 orang.

Tabel 8. Pengetahuan responden tentang cara seseorang menghindari seks diluar nikah di SMA Negeri 1 Berastagi Kabupaten Karo Tahun 2017

\begin{tabular}{lllc}
\hline No. & \multicolumn{1}{c}{ Pilihan } & \multicolumn{1}{c}{ Jawaban } & Jumlah \\
\hline 1 & $\begin{array}{l}\text { Menghindari } \\
\text { pergaulan bebas }\end{array}$ & Tidak tahu & - \\
\hline 2 & $\begin{array}{l}\text { Meningkatkan } \\
\text { pengetahuan } \\
\text { kesehatan } \\
\text { reproduksi }\end{array}$ & $\begin{array}{l}1 \text { item } \\
\text { jawaban } \\
\text { benar }\end{array}$ & 16x1=16 \\
\hline 3 & $\begin{array}{l}\text { Berhati-hati dalam } \\
\text { memilih teman }\end{array}$ & $\begin{array}{l}2 \text { item } \\
\text { jawaban } \\
\text { benar }\end{array}$ & $4 \times 1=4$ \\
\hline 4 & $\begin{array}{l}\text { Meningkatkan amal } \\
\text { ibadah }\end{array}$ & $\begin{array}{l}3 \text { item } \\
\text { jawaban } \\
\text { benar }\end{array}$ & $4 \times 1=4$ \\
\hline 5 & $\begin{array}{l}\text { Perhatian } \\
\text { pemantauan } \\
\text { tua }\end{array}$ & $\begin{array}{l}4 \text { item } \\
\text { jawaban } \\
\text { benar }\end{array}$ & $2 \times 4=8$ \\
\hline 6 & Tidak tahu & $\begin{array}{l}5 \text { item } \\
\text { jawaban } \\
\text { benar }\end{array}$ & $7 \times 2=14$ \\
& & Jumlah & 46 \\
\hline & & & \\
\hline
\end{tabular}

Dari tabel 8 diatas dapat diketahui bahwa Pengetahuan responden tentang cara seseorang menghindari seks diluar nikah di SMA Negeri 1 Berastagi Kabupaten Karo tahun 2017 yang paling banyak dipilih 
adalah memilih 1 item jawaban yang benar diantara 6 buah pilihan jawaban sebanyak 16 orang.

Tabel 9. Pengetahuan responden tentang cara menghindari impuls seks terhadap lawan jenis (pacar) di SMA Negeri 1 Berastagi Kabupaten Karo Tahun 2017

\begin{tabular}{llll}
\hline No. & Pilihan & Jawaban & Jumlah \\
\hline 1 & $\begin{array}{l}\text { Meningkatkan diri } \\
\text { kepada Tuhan }\end{array}$ & Tidak tahu & $4 \times 1=4$ \\
\hline 2 & $\begin{array}{l}\text { Mendengarkan } \\
\text { nasehat orang tua }\end{array}$ & $\begin{array}{l}1 \text { item } \\
\text { jawaban } \\
\text { benar }\end{array}$ & $9 \times 1=9$ \\
\hline 3 & $\begin{array}{l}\text { Menghindari berduaan } \\
\text { ditempat sepi }\end{array}$ & $\begin{array}{l}2 \text { item } \\
\text { jawaban } \\
\text { benar }\end{array}$ & $7 \times 1=7$ \\
\hline 4 & $\begin{array}{l}\text { Menghindari sentuhan } \\
\text { yang sifatnya dapat } \\
\text { merangsang }\end{array}$ & $\begin{array}{l}\text { 3 item } \\
\text { jawaban } \\
\text { benar }\end{array}$ & $11 \times 1=11$ \\
\hline 5 & $\begin{array}{l}\text { Bersikap rasional dan } \\
\text { wajar apabila jatuh } \\
\text { cinta }\end{array}$ & $\begin{array}{l}4 \text { item } \\
\text { jawaban } \\
\text { benar }\end{array}$ & $3 \times 2=6$ \\
\hline 6 & Tidak tahu & $\begin{array}{l}5 \text { item } \\
\text { jawaban } \\
\text { benar }\end{array}$ & $16 \times 2=32$ \\
& & Jumlah & 69 \\
\hline
\end{tabular}

Dari tabel 9 dapat diketahui bahwa Pengetahuan responden tentang cara menghindari impuls seks terhadap lawan jenis (pacar) di SMA Negeri 1 Berastagi Kabupaten Karo tahun 2017 yang paling banyak dipilih adalah memilih jawaban tidak tahu diantara 6 buah pilihan jawaban sebanyak 16.

Tabel 10. Pengetahuan responden tentang factorfaktor yang menyebabkan remaja melakukan hubungan seksual di SMA Negeri 1 Berastagi Kabupaten Karo Tahun 2017

\begin{tabular}{llll}
\hline No. & Pilihan & Jawaban & Jumlah \\
\hline 1 & $\begin{array}{l}\text { Pergaulan yang } \\
\text { terlalu bebas }\end{array}$ & Tidak tahu & - \\
\hline 2 & $\begin{array}{l}\text { Kurangnya } \\
\text { pengawasan dari } \\
\text { orang tua }\end{array}$ & $\begin{array}{l}1 \text { item } \\
\text { jawaban benar }\end{array}$ & $7 \times 1=7$ \\
\hline 3 & Mencoba-coba seks & $\begin{array}{l}\text { 2 item } \\
\text { jawaban benar }\end{array}$ & 20x1=20 \\
\hline 4 & Tersedianya alat & $\begin{array}{l}\text { 3 item } \\
\text { jawaban benar }\end{array}$ & $9 \times 1=9$ \\
& $\begin{array}{l}\text { kontrasepsi secara } \\
\text { bebas }\end{array}$ & $\begin{array}{l}4 \text { item } \\
\text { jawaban benar }\end{array}$ & $4 \times 2=8$ \\
\hline 5 & $\begin{array}{l}\text { Toleransi yang } \\
\text { terlalu longgar }\end{array}$ & $\begin{array}{l}5 \text { item } \\
\text { jawaban benar }\end{array}$ \\
\hline 6 & Tidak tahu & Jumlah & 64 \\
\hline
\end{tabular}

Dari tabel 10 diatas dapat diketahui bahwa Pengetahuan responden tentang cara menghindari impuls seks terhadap lawan jenis (pacar) di SMA Negeri 1 Berastagi Kabupaten Karo tahun 2017 yang paling banyak dipilih adalah memilih 2 item jawaban yang benar diantara 6 buah pilihan jawaban yaitu sebanyak 20 orang.

Tabel 11. Pengetahuan responden tentang dampak psikologis dari perilaku seks pranikah di SMA Negeri 1 Berastagi Kabupaten Karo Tahun 2017

\begin{tabular}{llll}
\hline No. & Pilihan & Jawaban & Jumlah \\
\hline 1 & Perasaan takut & Tidak tahu & $7 \times 1=7$ \\
\hline 2 & Depresi & $\begin{array}{l}\text { 1 item jawaban } \\
\text { benar }\end{array}$ & $11 \times 1=11$ \\
\hline 3 & Rendah diri & $\begin{array}{l}2 \text { item jawaban } \\
\text { benar }\end{array}$ & $10 \times 1=10$ \\
\hline 4 & Cemas & $\begin{array}{l}3 \text { item jawaban } \\
\text { benar }\end{array}$ & $9 \times 1=9$ \\
\hline 5 & Merasa berdosa & $\begin{array}{l}4 \text { item jawaban } \\
\text { benar }\end{array}$ & $4 \times 2=8$ \\
\hline 6 & Tidak tahu & $\begin{array}{l}5 \text { item jawaban } \\
\text { benar }\end{array}$ & $9 \times 2=18$ \\
\hline & & Jumlah & 63 \\
\hline
\end{tabular}

Dari tabel 11 diatas dapat diketahui bahwa Pengetahuan responden tentang dampak psikologis dari perilaku seks pranikah di SMA Negeri 1 Berastagi Kabupaten Karo tahun 2017 yang paling banyak dipilih yaitu memilih 1 item jawaban yang benar diantara 6 buah pilihan jawaban sebanyak 11 .

Tabel 12. Pengetahuan responden tentang Risiko yang dihadapi remaja akibat perilaku seks pranikah di SMA Negeri 1 Berastagi Kabupaten Karo Tahun 2017

\begin{tabular}{|c|c|c|c|}
\hline No. & Pilihan & Jawaban & Jumlah \\
\hline 1 & $\begin{array}{l}\text { Kehamilan yang } \\
\text { tidak diinginkan }\end{array}$ & Tidak tahu & - \\
\hline 2 & $\begin{array}{l}\text { Belum siap untuk } \\
\text { mengahadapi } \\
\text { kehamilan dan } \\
\text { persalinan }\end{array}$ & $\begin{array}{l}1 \text { item } \\
\text { jawaban benar }\end{array}$ & $7 \times 1=7$ \\
\hline 3 & $\begin{array}{l}\text { Menjadi orang tua } \\
\text { pada masa remaja }\end{array}$ & $\begin{array}{l}2 \text { item } \\
\text { jawaban benar }\end{array}$ & $14 \times 1=14$ \\
\hline 4 & $\begin{array}{l}\text { Terpaksa menikah } \\
\text { dini }\end{array}$ & $\begin{array}{l}3 \text { item } \\
\text { jawaban benar }\end{array}$ & $9 \times 1=9$ \\
\hline 5 & Aborsi & $\begin{array}{l}4 \text { item } \\
\text { jawaban benar }\end{array}$ & $9 \times 2=18$ \\
\hline 6 & Tidak tahu & $\begin{array}{l}5 \text { item } \\
\text { jawaban benar }\end{array}$ & $11 \times 2=22$ \\
\hline & & Jumlah & 70 \\
\hline
\end{tabular}

Dari tabel diatas dapat diketahui bahwa pengetahuan responden tentang Risiko yang dihadapi remaja akibat perilaku seks pranikah di SMA Negeri 1 Berastagi Kabupaten Karo tahun 2017 yang paling banyak dipilih adalah memilih 5 item jawaban yang benar diantara 6 buah pilihan jawaban yaitu sebanyak 11 . 
Tabel 13. Pengetahuan responden tentang dampak sosial yang timbul akibat melakukan seks pranikah di SMA Negeri 1 Berastagi Kabupaten Karo Tahun 2017

\begin{tabular}{|c|c|c|c|}
\hline No. & Pilihan & Jawaban & Jumlah \\
\hline 1 & Dikucilkan & Tidak tahu & $1 \times 1=1$ \\
\hline 2 & $\begin{array}{l}\text { Putus sekolah } \\
\text { karena hamil }\end{array}$ & $\begin{array}{l}1 \text { item } \\
\text { jawaban benar }\end{array}$ & $4 \times 1=4$ \\
\hline 3 & $\begin{array}{l}\text { Perubahan peran } \\
\text { menjadi seorang ibu }\end{array}$ & $\begin{array}{l}2 \text { item } \\
\text { jawaban benar }\end{array}$ & $15 \times 1=15$ \\
\hline 4 & $\begin{array}{l}\text { Dianggap wanita } \\
\text { yang tidak bermoral }\end{array}$ & $\begin{array}{l}3 \text { item } \\
\text { jawaban benar }\end{array}$ & $12 \times 1=12$ \\
\hline 5 & $\begin{array}{l}\text { Tekanan } \\
\text { masyarakat yang } \\
\text { mencela keadaan } \\
\text { tersebut }\end{array}$ & $\begin{array}{l}4 \text { item } \\
\text { jawaban benar }\end{array}$ & $6 \times 2=12$ \\
\hline \multirow[t]{2}{*}{6} & Tidak tahu & $\begin{array}{l}5 \text { item } \\
\text { jawaban benar }\end{array}$ & $12 \times 2=24$ \\
\hline & & Jumlah & 68 \\
\hline
\end{tabular}

Dari tabel 13 diatas dapat diketahui bahwa Pengetahuan responden tentang dampak sosial yang timbul akibat melakukan seks pranikah di SMA Negeri 1 Berastagi Kabupaten Karo tahun 2017yang paling banyak dipilih yaitu memilih 2 item jawaban yang benar diantara 6 buah pilihan jawaban yaitu sebanyak 15 orang.

Tabel 14. Pengetahuan responden tentang alasan remaja melakukan seks pranikah di SMA Negeri 1 Berastagi Kabupaten Karo Tahun 2017

\begin{tabular}{|c|c|c|c|}
\hline No. & Pilihan & Jawaban & Jumlah \\
\hline 1 & $\begin{array}{l}\text { Karena mereka } \\
\text { pelaku yang aktif } \\
\text { seksual }\end{array}$ & Tidak tahu & $4 \times 1=4$ \\
\hline 2 & $\begin{array}{l}\text { Karena suka dan } \\
\text { cinta pada } \\
\text { pasangannya }\end{array}$ & $\begin{array}{l}1 \text { item } \\
\text { jawaban benar }\end{array}$ & $19 \times 1=19$ \\
\hline 3 & $\begin{array}{l}\text { Karena menyukai } \\
\text { seks tersebut }\end{array}$ & $\begin{array}{l}2 \text { item } \\
\text { jawaban benar }\end{array}$ & $15 \times 1=15$ \\
\hline 4 & $\begin{array}{l}\text { Karena } \\
\text { keingintahuan yang } \\
\text { besar terhadap seks } \\
\text { itu sendiri }\end{array}$ & $\begin{array}{l}3 \text { item } \\
\text { jawaban benar }\end{array}$ & $6 \times 1=6$ \\
\hline 5 & $\begin{array}{l}\text { Dorongan seksual } \\
\text { yang tinggi }\end{array}$ & $\begin{array}{l}4 \text { item } \\
\text { jawaban benar }\end{array}$ & $3 \times 2=6$ \\
\hline \multirow[t]{2}{*}{6} & Tidak tahu & $\begin{array}{l}5 \text { item } \\
\text { jawaban benar }\end{array}$ & $3 \times 2=6$ \\
\hline & & Jumlah & 56 \\
\hline
\end{tabular}

Dari tabel 14 diatas dapat diketahui bahwa Pengetahuan responden tentang alasan remaja melakukan seks pranikah di SMA Negeri 1 Berastagi Kabupaten Karo tahun 2017 yang paling banyak dipilih adalah memilih 1 item jawaban yang benar diantara 6 buah pilihan jawaban yaitu sebanyak 19 .
Tabel 15. Pengetahuan responden tentang alasan lain remaja mau melakukan hubungan seks sebelum menikah di SMA Negeri 1 Berastagi Kabupaten Karo Tahun 2017

\begin{tabular}{|c|c|c|c|}
\hline No. & Pilihan & Jawaban & Jumlah \\
\hline 1 & $\begin{array}{ll}\text { Dipaksa } & \text { oleh } \\
\text { pacarnya } & \end{array}$ & Tidak tahu & $7 \times 1=7$ \\
\hline 2 & Suka sama suka & $\begin{array}{lr}1 & \text { item } \\
\text { jawaban benar }\end{array}$ & $15 \times 1=15$ \\
\hline 3 & Ingin mencoba & $\begin{array}{lr}2 & \text { item } \\
\text { jawaban benar }\end{array}$ & $7 x 1=7$ \\
\hline 4 & $\begin{array}{l}\text { Menanggap } \\
\text { hubungan yang } \\
\text { intim sehingga tidak } \\
\text { perlu ada batasan }\end{array}$ & $\begin{array}{lr}3 & \text { item } \\
\text { jawaban benar }\end{array}$ & $9 \times 1=9$ \\
\hline 5 & $\begin{array}{l}\text { Mengganggap seks } \\
\text { merupakan bagian } \\
\text { dari cinta }\end{array}$ & $\begin{array}{lr}4 & \text { item } \\
\text { jawaban benar }\end{array}$ & $4 \times 2=8$ \\
\hline 6 & Tidak tahu & $\begin{array}{lr}5 & \text { item } \\
\text { jawaban benar }\end{array}$ & $7 \times 2=14$ \\
\hline & & Jumlah & 60 \\
\hline
\end{tabular}

Dari tabel 15 diatas dapat diketahui bahwa Pengetahuan responden tentang alasan lain remaja mau melakukan hubungan seks sebelum menikah di SMA Negeri 1 Berastagi Kabupaten Karo tahun 2017 yang banyak dipilih yaitu memilih 1 item jawaban yang benar diantara 6 buah pilihan jawaban yaitu sebanyak 15 orang.

Tabel 16. Pengetahuan responden tentang dampak fisik yang timbul akibat hubungan seks pranikah di SMA Negeri 1 Berastagi Kabupaten Karo Tahun 2017

\begin{tabular}{llll}
\hline No. & \multicolumn{1}{c}{ Pilihan } & \multicolumn{1}{c}{ Jawaban } & Jumlah \\
\hline 1 & $\begin{array}{l}\text { Kehamilan yang } \\
\text { tidak diinginkan }\end{array}$ & Tidak tahu & $1 \times 1=1$ \\
\hline 2 & $\begin{array}{l}\text { Penyakit menular } \\
\text { seksual }\end{array}$ & $\begin{array}{l}1 \text { item } \\
\text { jawaban benar }\end{array}$ & $12 \times 1=12$ \\
\hline 3 & Kemandulan & $\begin{array}{l}\text { 2 item } \\
\text { jawaban benar }\end{array}$ & $13 \times 1=13$ \\
\hline 4 & Rasa sakitb yang & $\begin{array}{l}\text { 3 item } \\
\text { jawaban benar }\end{array}$ & $11 \times 1=11$ \\
\hline 5 & Hronis & $\begin{array}{l}4 \text { item } \\
\text { jawaban benar }\end{array}$ & $4 \times 2=8$ \\
\hline 6 & Tidak tahu & $\begin{array}{l}5 \text { item } \\
\text { jawaban benar }\end{array}$ & $9 \times 2=18$ \\
\hline \multicolumn{5}{l}{} & & Jumlah & 63 \\
\hline
\end{tabular}

Dari tabel diatas dapat diketahui bahwa pengetahuan responden tentang alasan lain remaja mau melakukan hubungan seks sebelum menikah di SMA Negeri 1 Berastagi Kabupaten Karo tahun 2017yang paling banyak dipilih yaitu memilih 2 item jawaban yang benar diantara 6 buah pilihan jawaban yaitu sebanyak 13 .

Jadi Jumlah item Pengetahuan $=839 / 1500=55,9$ $\%$ jadi dikategorikan Skor Pengetahuan Siswa adalah Kurang Baik. 


\section{B. PEMBAHASAN}

Berdasarkan hasil penelitian menunjukkan bahwa usia responden pada penelitian ini adalah usia 14-18 tahun disebut masa pertengahan remaja (Middle Adolescence). Sehingga pada umur ini remaja sangat rentan akan pergaulan bebas dan lebih mudah menerima informasi dari luar khususnya tentang Seksual Pranikah.Pengetahuan seksual pranikah remaja didapat dari berbagai sumber yaitu media elektronik,media cetak, teman guru dan orang tua. Hasil penelitian ini, remaja memperoleh informasi tentang seksual pranikah paling dominan dari internet ak sebanyak 42 orang (84\%) dan paling sedikit dari tidak ada informasi dari manapun sebanyak 1 orang $(5,9 \%)$ dan yang lainnya adalah dari guru,keluarga, teman-teman dan ini sesuai dengan penelitian Oktarina(2009) orang yang memiliki sumber informasi yang lebih banyak akan memiliki pengetahuan yang luas pula. Hal ini dikarenakan karena ada anggapan tabu untuk berbicara seks yang masih menancap dalam benak sebagian masyarakat. Akibatnya anak-anak yang beranjak remaja jarang yang mendapat bekal pengetahuan seks yang cukup dari orang tua sekalipun. Mereka paling tidak nyaman kalau membahas soal seks dengan anggota keluarga.terkadang kesalahan terletak pada orang tua itu sendiri yaitu dikarenakan orang tua sering tidak memahami perubahan yang terjadi pada remaja. Maka pendidikan seks bagi remaja menjadi program yang harus segera dilaksanakan. Salah satu informasi yang berperan penting bagi pengetahuan adalah media massa. Pengetahuan masyarakat khususnya tentang kesehatan bisa didapat dari berbagai sumber antara lain : media cetak,tulis,elektronik, pendidikan sekolah dan penyuluhan.

Tingkat pengetahuan remaja tentang seks pranikah SMA Negeri 1 Berastagi Kabupaten Karo tahun 2017 menunjukkan bahwa responden berpengetahuan kurang baik karena setelah dijumlahkan nilai item maka skornya hanya $58 \%$ sedangkan dikategorikan baik jika skor item > $76 \%$ maka hal ini disesuaikan dengan teori Nursalam (2008) yaitu remaja mampu menjawab dengan benar jika skor nilai 76-100\% dari semua pertanyaan. Hasil penelitian tersebut tidak sesuai dengan penelitian penelitian Darmais (2009) dengan hasil pengetahuan baik bisa mencapai $82,5 \%$.

Pengetahuan merupakan faktor pemudah (predisposing faktor) bagi siswa untuk terlaksananya perilaku yang baik. Dengan demikian faktor ini menjadi pemicu atau anteseden terhadap perilaku yang menjadi atau motivasi bagi tindakannya akibat tradisi atau kebiasaan,kepercayaan, tingkat pendidikan dan tingkat social ekonomi (Notoatmodjo,S, 2007).

Menurut Sari S (2006) ada keeratan hubungan antara pengetahuan dalam upaya untuk memperbaiki perilaku. Dengan demikian meningkatkan pengetahuan akan memberikan hasil yang cukup berarti memperbaiki perilaku. Hal ini sesuai dengan pernyataan Rogers dalam Sari S(2006) yang mengatakan bahwa pengetahuan kognitif merupakan domain yang sangat penting bagi terbentuknya perilaku, dan perilaku yang didasari pengetahuan akan bertahan lebih langgeng daripada perilaku yang tidak didasari pengetahuan.

\section{KESIMPULAN DAN SARAN}

\section{Kesimpulan}

1. Umur responden yang terbanyak adalah umur 15 tahun yaitu sebanyak 15 orang $(44,1 \%)$ dan yang paling sedikit berumur 14 dan 18 tahun masing-masing sebanyak lorang $(2,9 \%)$.

2. Sumber informasi tentang kesehatan responden di SMA Negeri 1 Berastagi Kabupaten Karo tahun 2017 paling banyak adalah dari adalah media cetak dan internet yaitu masing-masing 21 orang $(61,8 \%)$ dan paling sedikit dari telepon genggam dan tidak ada dapat informasi dari manapun masing-masing sebanyak 2 orang $(5,9 \%)$.

3. Pengetahuan responden tentang seks pranikah sebagian besar berpengetahuan kurang baik yaitu sebanyak 56\% setelah dijumlah semua skor penilaian.

\section{Saran}

1. Perlunya upaya penyuluhan seks pranikah disertai kesempatan untuk berkonsultasi dengan guru, konsultan psikolog di sekolah atau guru agama. Peran guru bimbingan dan penyuluhan (BP)pun sangat penting sebaiknya pihak sekolah memberikan peningkatan pengetahuan tentang seks pranikah pada siswa SMA Negeri 1 Berastagi Kabupaten Karo dengan bertahap dan berkelanjutan dari guru BP, instansi terkait dan guru agamapun sebaiknya lebih menekankan pada pendidikan moral.

2. Sebagai bahan acuan bagi penelitian ini hendaknya dapat dikembangkan pada penelitian ini selanjutnya akan meneliti lebih luas tentang faktor-faktor penyebab seks pranikah pada remaja.

\section{DAFTAR PUSTAKA}

Azwar S,2009. Sikap Manusia Teori dan Pengukurannya.Yogyakarta:Pustaka Pelajar offset.

Adikusumo I,2005. "Sikap Remaja Terhadap Seks Bebas di Kota : Perspektif Kajian Budaya".

Hidayat H,2007. Metode Kebidanan Teknik Analisa Data. Salemba Medika.Jakarta.

Kementrian Kesehatan RI. Direktorat Jenderal Pengendalian Penyakit dan Penyehatan Lingkungan, 2011.Jakarta.

Notoatmodjo.S.,2007.Promosi Kesehatan dan Ilmu Perilaku. Rineka Cipta.Jakarta.

Sari S,2006. Hubungan faktor Predisposisi dengan Perilaku Personal Higiene anak Jalanan Bimbingan.Skripsi,Keperawatan Komunitas Fakultas Ilmu Keperawatan Universitas Padjajaran Bandung.

Sarwono,S.W,2006. Psikologi Remaja.Jakarta. PT.Raja Grafindo Persada.

Sugiyono,2007. Statistik Untk Penelitian. Alfabeta.Bandung. 